University for Business and Technology in Kosovo

UBT Knowledge Center

UBT International Conference

2012 UBT International Conference

Nov 2nd, 9:00 AM - Nov 3rd, 5:00 PM

\title{
Motivational Working Environment in Small and Medium Local Enterprises in Kosovo
}

Dritan Abazi

D\&A Fin, drabazi@hotmail.com

Elona Nazari

University of Tirana, elonanazari@yahoo.com

Follow this and additional works at: https://knowledgecenter.ubt-uni.net/conference

Part of the Business Commons

\section{Recommended Citation}

Abazi, Dritan and Nazari, Elona, "Motivational Working Environment in Small and Medium Local

Enterprises in Kosovo" (2012). UBT International Conference. 50.

https://knowledgecenter.ubt-uni.net/conference/2012/all-events/50

This Event is brought to you for free and open access by the Publication and Journals at UBT Knowledge Center. It has been accepted for inclusion in UBT International Conference by an authorized administrator of UBT Knowledge Center. For more information, please contact knowledge.center@ubt-uni.net. 


\title{
Motivational Working Environment in Small and Medium Local Enterprises in Kosovo.
}

\author{
Dritan Abazi, PhD Candidat \\ Senior Consultant at Microfinance Strategy SARL, Switzerland \\ Managing Partner at D\&A Fin. Partner, Albania \\ drabazi@hotmail.com \\ Elona Nazari, PhD \\ Marketing Department \\ Economic Faculty, Tirana University, Albania \\ elonanazari@yahoo.com
}

\begin{abstract}
High-performance companies compete in order to gain new customers and keeping the existing customers and this makes it to treat their customers with a high level of service, but to offer a high level of service the organization should possess a highly motivated work force. The aim of our study: is not focused on the assessment of a particular company, but the evaluation of several companies, small and medium enterprises which are established by local Kosovo owners.

The analysis of responses to questionnaires, observe that small and medium local companies in Kosovo have inefficiencies in the direction of their staff.

There is a lack of performance evaluation of staff, lack of delegated responsibility of the staff, lack of participating in decisions that impact their daily work of the staff and lack of formal performance appraisal of the staff.

Kosovo, as many other countries of the region is a developing country where business plays its critical role in this activity. Too many foreign companies see the developing countries as an opportunity to invest, as new markets where they can increase the number of clients. The foreign companies are companies with professional expertise and their equity cover some folds the local company's equity. The market is becoming very competitive and will become more competitive in the future and to local companies will be more difficult to compete if they are not able to improve the working environment for keeping the existing employees and attracting talented employees.
\end{abstract}

Key words: motivation, satisfaction in the work place, organizational structure etc. 